\title{
"BUSINESS CASE" ACTIVITIES IN AVIATION. EVIDENCE FROM RESEARCH AT KATOWICE AIRPORT
}

DATA PRZESŁANIA: 10.12.2015 |DATA AKCEPTACJI: 12.12.2015 |JEL CODE: M21

\section{Assoc. Prof., Ing., Navigator Andrzej Fellner}

Katedra Technologii Lotniczych Wydziału Transportu Politechniki Śląskiej

email: afellner@o2.pl

\begin{abstract}
During performing researches as part of the European programs associated with the implementation of new techniques and the technology in aviation, it turned out that it is necessary to prepare a "Business Case" document. During the completion of three international projects, as part of workshops, there were accepted certain theoretical models of drawing these documents up. There was a need to prepare the appropriate model solution for every country. The article is presenting such model as well as method of business analysis which should be applied in the air transport during the implementation of new techniques and the technology. The algorithm of execution of the "BUSINESS CASE" was presented in the following sections of the material - its validation took place during the international project SHERPA (Support ad-Hoc Eastern Region Pre-operational Actions in the GNSS).
\end{abstract}

KEYWORDS BUSINESS CASE, GNSS, SHERPA, air transport, airport

\section{INTRODUCTION}

Katowice is a city located within the Silesian metropolitan area in the South of Poland. This region had one of the highest scores in joint population density in Poland, with 180 persons per square kilometer and the total population of the Silesian metropolitan area being approximately 4.7 million. Such great potential plays an important role in air transport which stimulates regional employment and economic growth. The central point of air transport system in Silesian metropolitan area is Katowice Airport (EPKT) - one of the largest regional airports in Poland, the largest airport in Silesia and one of the most dynamically developing Polish airports. In 2015 EPTK/Katowice Airport handled 3,069,279 passengers (2,695,732 in 2014, 13\% growth), 
31,727 air operations $(28,771$ in 2014) and 16,119 tons of cargo (16,269 in 2014). Moreover, EPKT took over a part of air traffic and passenger traffic due to World Youth Days in Kraków.

In order to strengthen its capacity and business activities, there was made a model study of Business Case for implementation of special aviation procedures. These documents are a specific tool supporting planning and decision-making at aerodromes and airports, especially assisting decisions related to capital investment, products or services development, investments and products (Operational..., 2007; Standard..., 2013). A business case was conducted at Katowice Airport according to (Guidance..., 2012; Guidance..., 2013) and based on standards and recommended practices of ICAO (RNAV..., 2009) and EUROCONTROL (Standard..., 2013). More specifically, in the following sections is presented business case for implementation of a LPV (Localizer Performance with Vertical Guidance) approach - the kind of Required Navigation Performance Approach (RNP APCH) (ICAO..., 2012).

\section{SCENARIO CHARACTERISTICS FOR KATOWICE AIRPORT}

The business case activities take into account whether an ILS is available or not at the examined runway (RWY 09) of airport and whether it has an impact on financial results. The main characteristics of Katowice Airport (EPKT) are presented in table 1 and were defined in SHERPA report (Fellner, 2013) as well as in AIP Poland (Aeronautical...).

Table 1. Basic Katowice Airport data

\begin{tabular}{|l|l|}
\hline \multicolumn{1}{|c|}{ Name } & \multicolumn{1}{c|}{ Katowice Airport } \\
\hline ICAO code & EPKT \\
\hline IATA code & KTW \\
\hline Numbers of runaways & RWY 09 RWY 27 RWY 27D \\
\hline Threshold where to implement LPV & RWY 09 \\
\hline WGS-84 coordinates & $50^{\circ} 28^{\prime} 27^{\prime \prime} \mathrm{N} ; 019^{\circ} 04^{\prime} 48^{\prime \prime} \mathrm{E}$ \\
\hline ILS equipped on examined RWY 09? & No \\
\hline Elevation & $1007 \mathrm{ft}$. \\
\hline Reference temperature & $25^{\circ} \mathrm{C}$ \\
\hline Types of traffic permitted & IFR/YFR \\
\hline
\end{tabular}

Source: Fellner, 2013.

\section{COSTS OF IMPLEMENTATION PROCEDURE}

Typical costs related to the implementation of a LPV (Localizer Performance with Vertical Guidance) approach procedure can be broken down into aspects depicted in the table below. Costs related to RWY physical characteristics maybe included as required by the scenario: lightning systems, airfield works, obstacles removal, etc. These can be very different per scenario. In the case of publishing the LPV as an ILS back-up no costs are foreseen (Fellner, 2013). Details are presented in table 2 . 
Table 2. Scenario of implementation costs

Source: Fellner, 2013.

\begin{tabular}{|l|c|}
\hline \multicolumn{1}{|c|}{ Activity } & Cost [KEUR] \\
\hline LPV procedure design & 19,200 \\
\hline Safety Study & 4,800 \\
\hline Obstacles survey & 13,200 \\
\hline Approval by authority & 2,400 \\
\hline Testing (Flight Check) & 19,180 \\
\hline Publication & 1,200 \\
\hline Other/s (specify and add new rows) & - \\
\hline
\end{tabular}

\section{AIRPORT'S OPERATING FEES}

In order to simplify the calculation of benefits derived from the increased number of completed landings thanks to the implementation of LPV operations, the following is applied: landing fee based on aircraft maximum take-off weight (MTOW), parking fee only applies if parking lasts for more than 4 hours (Fellner, 2013). Mentioned fees are shown in table 3.

Table 3. Flat rates assumed per aircraft category

\begin{tabular}{|l|c|c|c|c|}
\hline & CAT A & CAT B & CAT C & CAT D \\
\hline MTOW (tons) & 1 & 6 & 78 & 220 \\
\hline Landing fee $(€)^{1}$ & 50 & 60 & 780 & 2,200 \\
\hline Parking time $(\mathrm{h})^{2}$ & $>4$ & $>4$ & $>4$ & $>4$ \\
\hline Parking fee $(€)$ & 6 & 12 & 156 & 440 \\
\hline
\end{tabular}

1 These are estimated values of charges in euro because all charges set forward in the tariff are expressed in Polish zlotys (PLN).

2 Charges are not levied for aircraft parking for up to 4 hours.

Source: Fellner, 2013.

\section{REVIEW OF TOTAL AIRCRAFT LANDINGS}

Following the model described in above paragraphs, the first task is to collect statistics on the total number of landings at the airport. Traffic forecasts have been also established for the nearmidterm period. It is important to note that the next table presents only landings' statistics (not total number of operations, which would include departures). Next step is to establish how many of the above operations are conducted towards the thresholds where LPVs are to be implemented. Runway in use (airport configuration) typically depends on the prevailing wind direction at the airport, as aircraft shall take-off and land against the wind (Fellner, 2013). Details are presented in tables 4 and 5. 
Table 4. Total number of airport landings

\begin{tabular}{|l|c|c|c|c|}
\hline \multicolumn{1}{|c|}{ Year } & PAX landing ops & Change (\%) & Cargo landing ops & Change (\%) \\
\hline 2007 & 10,829 & - & 1,415 & - \\
\hline 2008 & 12,058 & 11.35 & 1,457 & 2.97 \\
\hline 2009 & 11,960 & -0.81 & 1,143 & 5.25 \\
\hline 2010 & 12,182 & 1.86 & 1,203 & 14.71 \\
\hline 2011 & 13,250 & 8.77 & 1,380 & -1.81 \\
\hline 2012 & 13,937 & 5.18 & 1,355 & 17.34 \\
\hline 2013 & 14,840 & 6.48 & 1,590 & 15.22 \\
\hline 2014 & 15,963 & 7.57 & 1,832 & 11.19 \\
\hline 2015 & 17,405 & 9.03 & 2,037 & 85.32 \\
\hline 2016 & 18,394 & 5.68 & 3,775 & 17.99 \\
\hline 2017 & 19,322 & 5.05 & 4,454 & 8.64 \\
\hline 2018 & 20,201 & 4.55 & 4,839 & 5.95 \\
\hline 2019 & 20,680 & 2.37 & 5,127 & \\
\hline
\end{tabular}

Source: Fellner, 2013.

Table 5. Runaway configuration of EPKT airport

Source: Fellner, 2013.

\begin{tabular}{|l|l|}
\hline \multicolumn{2}{|c|}{ Runaway configurations (\%) } \\
\hline THR 09 configuration & 5 \\
\hline THR 27 configuration & 95 \\
\hline
\end{tabular}

By applying RWY usage percentages to the total number of landings, it will be possible to estimate the number of landings performed to the thresholds where LPV is to be implemented. This is presented in table 6 (Fellner, 2013). As no ILS procedures are published at runway/s where LPV is to be implemented, the figures in table 6 can be directly used for subsequent steps of the study.

Table 6. Total number of landings at LPV runaways

\begin{tabular}{|c|c|c|}
\hline \multicolumn{3}{|c|}{ Total number of landings at LPV runways } \\
\hline Year & PAX ops & Cargo ops \\
\hline 2013 & 742 & 80 \\
\hline 2014 & 798 & 92 \\
\hline 2015 & 870 & 102 \\
\hline 2016 & 920 & 189 \\
\hline 2017 & 966 & 223 \\
\hline 2018 & 1,010 & 242 \\
\hline 2019 & 1,034 & 256 \\
\hline 2020 & 1,034 & 271 \\
\hline
\end{tabular}

Source: Fellner, 2013. 


\section{DISRUPTION PROBABILITY PER APPROACH TYPE}

The disruption probability per approach type is calculated based upon a combination of the approach $\mathrm{OCH}$ (Obstacle Clearance Height) and meteorological conditions at the time of approach. The main idea is that if the $(\mathrm{M}) \mathrm{DA} /(\mathrm{M}) \mathrm{DH}$ of an approach is greater than the recorded cloud ceiling or the recorded visibility exceeds the required level, then a disruption will ensue. To conduct such analysis it is necessary to know the lowest MDH (Minimum Descent Height) provided by conventional navigation means at the implementation RWY - see table 7.

Table 7. MDH per aircraft category at RWY 09

\begin{tabular}{|c|c|c|c|c|c|}
\hline \multicolumn{5}{|c|}{ MDH $(\mathrm{ft})$} \\
\hline RWY & NAVAID & CAT A & CAT B & CATC & CAT D \\
\hline 09 & VOR & 427 & 443 & 476 & 509 \\
\hline
\end{tabular}

Source: Fellner, 2013.

For the further analysis, meteorological data were collected from the Aeronautical Meteorological Station Katowice - Pyrzowice Airport from period 01.01.2012-31.12.2013 (Fellner, 2013). With this data, a disruption probability per a/c category was calculated, and the results are presented in the following table.

Table 8. Disruption probability for NPA landings

\begin{tabular}{|l|c|c|c|c|}
\hline \multicolumn{5}{|c|}{ Disruption probability for NPA landings (\%) } \\
\hline & CAT A & CAT B & CAT C & CAT D \\
\hline Disruption due to cloud ceiling & 10.6 & 11.2 & 11.8 & 12.8 \\
\hline Disruption due to visibility & 8.4 & 9.6 & 10.4 & 10.9 \\
\hline TOTAL & 18.9 & 20.8 & 22.2 & 23.7 \\
\hline
\end{tabular}

Source: Fellner, 2013.

\section{AIRCRAFT NPA DISRUPTIONS}

The total number of NPA (Non-Precision Approach) disrupted landings is equal to the product of the number of NPA landings per year multiplied by the probability of disruption for the particular approach type. As shown in tables 9 and 10, the first step is to estimate the percentage of landings executed per aircraft category (Fellner, 2013).

Table 9. Percentage of landings per aircraft category

\begin{tabular}{|c|c|c|}
\hline CAT A & CAT B & CAT C \\
\hline 3.78 & 14.67 & 81.27 \\
\hline
\end{tabular}

Source: Fellner, 2013. 
Table 10. Number of NPA disrupted landings

\begin{tabular}{|l|c|c|c|c|c|c|c|c|}
\hline \multicolumn{9}{|c|}{ Number of NPA disrupted landings } \\
\hline & \multicolumn{2}{|c|}{ CAT A } & \multicolumn{2}{c|}{ CAT B } & \multicolumn{2}{c|}{ CAT C } & \multicolumn{3}{c|}{ CAT D } \\
\hline Year & PAXops & Cargo ops & PAX ops & Cargo ops & PAX ops & Cargo ops & PAX ops & Cargo ops \\
\hline 2013 & 5 & 1 & 23 & 2 & 134 & 14 & 0 & 0 \\
\hline 2014 & 6 & 1 & 24 & 3 & 144 & 17 & 1 & 0 \\
\hline 2015 & 6 & 1 & 27 & 3 & 157 & 18 & 1 & 0 \\
\hline 2016 & 7 & 1 & 28 & 6 & 166 & 34 & 1 & 0 \\
\hline 2017 & 7 & 2 & 29 & 7 & 175 & 40 & 1 & 0 \\
\hline 2018 & 7 & 2 & 31 & 7 & 183 & 44 & 1 & 0 \\
\hline 2019 & 7 & 2 & 32 & 8 & 187 & 46 & 1 & 0 \\
\hline 2020 & 7 & 2 & 32 & 8 & 187 & 49 & 1 & 0 \\
\hline
\end{tabular}

Source: Fellner, 2013.

\section{REDUCTION IN DISRUPTIONS}

To eliminate number of NPA disrupted landings, there shall be flight tests conducted by using the new LPV operation designed for the implementation at RWY's. But before conducting these exercises, assumption on the different LPV navigation capabilities per aircraft categories will need to be established (Fellner, 2013) - it is presented in table 11.

Table 11. Aircraft LPV navigation capability

\begin{tabular}{|c|c|c|c|}
\hline \multicolumn{4}{|c|}{ LPV equipage per category (\%) } \\
\hline CAT A & CAT B & CAT C & CAT D \\
\hline 70 & 40 & 20 & 10 \\
\hline
\end{tabular}

Source: Fellner, 2013.

Next step is to consider the LPV Obstacle Clearance Heights per aircraft category (A, B, C, D) for Required Navigation Performance Approach at RWY 09 - which is shown in table 12.

Table 12. LPV OCH per aircraft category at RWY 09

\begin{tabular}{|c|c|c|c|c|c|}
\hline \multicolumn{6}{|c|}{ OCH $(\mathrm{ft})$} \\
\hline RWY & RNP APCH & CAT A & CAT B & CAT C & CAT D \\
\hline 09 & RNAV & 244 & 256 & 264 & 275 \\
\hline
\end{tabular}

Source: Fellner, 2013.

The last step is to calculate the total number of disrupted landings after LPV implementation. This calculation was made for the period 2013-2020. What is more, it took into account passengers operations (PAX ops) as well as cargo operations (Cargo ops). Results are presented in the table below. It is worth noticing that every year the number of LPV disrupted landings peaked during passengers operations for CAT C. The number of LPV disrupted landings is included in table 13. 
Table 13. Number of LPV disrupted landings

\begin{tabular}{|l|c|c|c|c|c|c|c|c|}
\hline \multicolumn{9}{|c|}{ Number of LPV disrupted landings } \\
\hline \multirow{2}{*}{ Year } & \multicolumn{2}{|c|}{ CAT A } & \multicolumn{2}{c|}{ CAT B } & \multicolumn{2}{c|}{ CAT C } & \multicolumn{2}{c|}{ CAT D } \\
\cline { 2 - 9 } & PAX ops & Cargo ops & PAX ops & Cargo ops & PAX ops & Cargo ops & PAX ops & Cargo ops \\
\hline 2013 & 2 & 0 & 5 & 1 & 13 & 1 & 0 & 0 \\
\hline 2014 & 2 & 0 & 5 & 1 & 14 & 2 & 0 & 0 \\
\hline 2015 & 3 & 0 & 6 & 1 & 16 & 2 & 0 & 0 \\
\hline 2016 & 3 & 1 & 6 & 1 & 16 & 3 & 0 & 0 \\
\hline 2017 & 3 & 1 & 6 & 1 & 17 & 4 & 0 & 0 \\
\hline 2018 & 3 & 1 & 7 & 2 & 18 & 4 & 0 & 0 \\
\hline 2019 & 3 & 1 & 7 & 2 & 18 & 5 & 0 & 0 \\
\hline 2020 & 3 & 1 & 7 & 2 & 18 & 5 & 1 & 0 \\
\hline
\end{tabular}

Source: Fellner, 2013.

\section{CONCLUSION}

Total cost savings are defined with respect to the base case and are calculated by applying a standard cost per disruption. The benefits for the airport will be those generated by the number of landings successfully completed thanks to the superior performances of LPV operations in contrast with NPA operations. To conduct such assessment it is necessary to apply the fees to the landing figures of table 10 and table 13. The following table 14 is filled according to the guidelines above.

Table 14. Benefits derived from LPV implementation [€]

\begin{tabular}{|l|c|c|c|}
\hline Year & $\begin{array}{c}\text { Non-collected fees in } \\
\text { conv. environment }\end{array}$ & $\begin{array}{c}\text { Non-collected fees in } \\
\text { RNP APCH environment }\end{array}$ & $\begin{array}{c}\text { Benefit derived from } \\
\text { LPV implementation }\end{array}$ \\
\hline 2013 & 117,240 & 11,380 & 105,860 \\
\hline 2014 & 129,750 & 12,940 & 116,810 \\
\hline 2015 & 140,850 & 14,610 & 126,240 \\
\hline 2016 & 160,640 & 15,440 & 145,200 \\
\hline 2017 & 172,510 & 17,000 & 155,519 \\
\hline 2018 & 181,990 & 17,900 & 164,090 \\
\hline 2019 & 186,790 & 18,680 & 168,110 \\
\hline 2020 & 189,130 & 18,680 & 170,450 \\
\hline
\end{tabular}

Source: Fellner, 2013.

In summary, the business case for implementation of a LPV approach at EPKT was based on standards and recommended practices of ICAO (Eurocontrol, 2009) as well as EUROCONTROL (Standard..., 2013) as part of a research conducted by SHERPA, which was financed by the EU (Support ad-Hoc Eastern Region Pre-operational Actions in the GNSS). The algorithm of execution of such analysis was presented in the sections above. As follows from the calculation, total benefit derived from LPV implementation over the period 2013-2020 for EPKT amounts to 1,152,270 euros. 


\section{REFERENCES}

Aeronautical Information Publication of Poland, AD EPKT 1-1, PANSA, p. 163.

Guidance Part 1: Scenarios Procedure Design and Business Case. SHERPA PANSA-NSRD21EP, 30.11.2012.

Guidance Part 2: Business Case and EGNOS Service Provision. SHERPA PANSA-NSRD2IEP, 27.02.2013. Operational and Functional model of LPV approaches in the ECAC area, OFM-LPV 2.0, 23.04.2007.

ICAO. Performance Based Navigation Manual. Doc 9613, fourth edition. 2012.

Eurocontrol. RNAV Approach Benefits Analysis - Final Report, 20/05/2009.

Fellner, A. (2013). Polish National Scenario Report. GSA Prague. SHERPA-PANSA NSR-D21EP, p. 3-30. Standard Inputs for Eurocontrol Cost Benefit Analyses. (2013). Eurocontrol, p. 5-37.

“Business case" w działalności lotniczej. Wyniki badań w katowickim porcie lotniczym

STRESZCZENIE Podczas wykonywania badań w ramach europejskich programów związanych $\mathrm{z}$ implementacją nowych technik i technologii w lotnictwie, okazało się niezbędne przygotowanie analizy biznesowej w formie dokumentu „Business Case”. W wyniku zrealizowania trzech międzynarodowych projektów oraz walidacji przyjętych założeń podczas zajęć warsztatowych, został zaakceptowany i przyjęty na forum europejskim teoretyczny model sporządzania tego dokumentu. Na tej podstawie konieczne było przygotowanie odpowiedniego rozwiązania modelowego w każdym państwie. W artykule przedstawiono zarys teoretyczny przyjętego modelu jako metody analizy handlowej, która powinna być zastosowana w transporcie lotniczym, podczas wprowadzania nowych technik i technologii. Algorytm wykonania dokumentu „Business Case” został przedstawiony w kolejnych częściach materiału a jego walidacja nastąpiła podczas międzynarodowego projektu SHERPA (Support ad-Hoc Eastern Region Pre-operational Actions w GNSS), w ramach którego implementowano 21 procedur podejścia RNAV GNSS na polskich lotniskach.

SŁOWA KLUCZOWE Business Case, GNSS, SHERPA, air transport, airport

Translated by Andrzej Fellner 